\title{
Geotechnologies and Soil Mapping for Delimitation of Management Zones as an Approach to Precision Viticulture
}

\author{
José Maria Filippini Alba, ${ }^{1}$ Carlos Alberto Flores, ${ }^{1}$ and Alberto Miele ${ }^{2}$ \\ ${ }^{1}$ Empresa Brasileira de Pesquisa Agropecuária, Centro de Pesquisa Agropecuária de Clima Temperado, P.O. Box 403, \\ 96010-971 Pelotas, RS, Brazil \\ ${ }^{2}$ Empresa Brasileira de Pesquisa Agropecuária, Centro Nacional de Pesquisa de Uva e Vinho, P.O. Box 130, \\ 95701-008 Bento Gonçalves, RS, Brazil \\ Correspondence should be addressed to José Maria Filippini Alba; jose.filippini@embrapa.br
}

Received 12 September 2016; Revised 1 December 2016; Accepted 28 December 2016; Published 16 February 2017

Academic Editor: Claudio Cocozza

Copyright (C) 2017 José Maria Filippini Alba et al. This is an open access article distributed under the Creative Commons Attribution License, which permits unrestricted use, distribution, and reproduction in any medium, provided the original work is properly cited.

\begin{abstract}
Data of the physical and chemical properties of soils from three vineyards located in Vale dos Vinhedos, Bento Gonçalves, Rio Grande do Sul state, in southern Brazil, were processed. Soil mapping was performed by means of four profiles and the digital elevation model in detailed scale. Then, superficial soils $(0-20 \mathrm{~cm})$ were sampled according to a grid pattern. Analysis of variance (ANOVA), kriging, and unsupervised classification methods were applied on physical and chemical data of superficial soils sampled according to grid pattern. This study aimed to compare both methods, the conventional soil mapping and the map produced with superficial soil sampling, about their potential for definition of the management zones, as an approach for precision agriculture. Maps elaborated by conventional soil mapping overlapped partially with the maps derived from superficial sampling, probably due to the specific methodological differences of each case. Anyway, both methods are complementary because of the focus on vertical variability and horizontal variability, respectively. In that sense, slope appears as significant edaphic parameter, due to its control on water circulation in the profile of soil.
\end{abstract}

\section{Introduction}

Notable advances in pedological research were reached in the 1990s, after a period of stagnancy, when a significant search for a rational use of natural resources and the equilibrium of biogeochemical cycles took place. In this way, monitoring and evaluation of soil resources began a new age, due to the quality of information derived from new technologies as geographical information systems (GIS) and remote sensing. Tayari et al. [1] discussed the relation among GPS, GIS, and precision agriculture (PA).

These technologies also contributed to improve precision viticulture, that is, "precision farming (or PA) applied to optimize vineyard performance, in particular maximizing grape yield and quality while minimizing environmental impacts and risk" [2]. According to McBratney et al. [3] "the definition of precision agriculture is still evolving as technology changes and our understanding of what is achievable grows. Over the years the emphasis has changed from simply 'farming by soil', through variable rate technologies, to vehicle guidance systems and will evolve to product quality and environmental management". Actually, in a more contemporaneous definition, "PA is a whole-farm management approach using information technology, satellite positioning data, remote sensing and proximal data gathering. These technologies seek improving returns on inputs while potentially reducing environmental impacts. The state-of-the-art of PA on arable land, permanent crops and within dairy farming are reviewed, mainly in the European context, altogether with some economic aspects of the adoption of PA" [4].

SCORPAN model for soil mapping considers the pedological parameters as a mathematical function evolving several factors: soil, climate, organisms (microorganisms, vegetation, or land use), relief, parent material, age, and spatial position [5, 6]. McBratney et al. [5] mentioned three main scales in pedometry: 
(1) national context with resolution larger than $2 \mathrm{~km}$;

(2) drainage basins and landscape need resolution between $20 \mathrm{~m}$ and $2 \mathrm{~km}$;

(3) local context with resolution lesser than $20 \mathrm{~m}$ (the order 0 of USDA survey evolves pixel size lesser than $5 \mathrm{~m} \times 5 \mathrm{~m}$ for applications in precision agriculture).

Soils are mainly components of "terroir" in viticulture [7]; however their survey is expensive and there is no direct relation to the type of wine. Cheaper methods of survey would be provided by the "geological model" or the "geomorphological model." Anyway, the mapped units do not agree with the classes of soil occurring in a vineyard due to scale problems, although there are agronomic variations intraunits of soil, according to small organic matter content changes or oscillations of horizon thickness. By this reason, new technologies must be used, as for instance digital elevation models, GIS, electric resistivity measures or remote sensing, aiming an efficient survey for the management of viticulture.

From a geospatial perspective, Flores et al. [8] considered each class of soil a management zone. However, FilippiniAlba et al. [9] integrated the classes of soil from the three vineyards by similarity, location and practical reasons, in five management zones. In that sense, Filippini-Alba et al. [10] implemented a microzoning in one vineyard, based on four variables: (1) content of clay; (2) organic matter level; (3) saturation of bases; (4) stoniness. Preferential class of aptitude was $150-350 \mathrm{~g} \cdot \mathrm{kg}^{-1},<2.5 \%, 20-49 \%$, and $<0.5 \%$ for (1) to (4), respectively, and locates mainly on CXve 2 and CXve 3 units, northern part of the vineyard. Coincidence within management zones is not exactly but is very similar.

Several papers discuss the effects of phenolic compounds in wine [11], but the amount of papers is significantly reduced if the influence of soil on phenolic compounds is considered. A diversity of taxonomic classes is associated with the vineyards of Vale dos Vinhedos, which change radically in a tiny scale occasionally. These changes affect the content of phenolic compounds in the wine produced $[11,12]$. Grenache noire vines planted with water or nitrogen restriction are related to grapes enriched with sugars and anthocyanins levels [13]. Moreover, the authors concluded that the type of soil does not affect the quality of grapes; however, this property would be associated with soil depth.

The previous developing suggest several questions related to the management of the vineyard and the use of geospatial modeling from a precision agriculture (PA) perspective or the application of a more realistic approach, including management zones defined by conventional soil mapping or GIS modeling. On the one hand we have the precision of geotechnologies and the horizontal geospatial variability; on the other hand we have the recognized pedological model, where the analysis of the vertical variability and the associated cycle of water have provided so many benefits for agriculture. These approaches are discussed in some way in this paper considering three vineyards located on Vale dos Vinhedos, Bento Gonçalves, Rio Grande do Sul state, in southern Brazil. Some more specific objectives/questions are the following. (1) Soil mapping is an expensive procedure, costly, and time consuming; is there some technique with the same level of efficiency and cheaper in the perspective of PA? (2) Geospatial analysis and GIS procedures are related to PA, but standard procedures for interpolation and fusion data are generally absent from bibliographies. A specific method in that sense is presented and discussed here. (3) How are soil units related to viticulture variables?

\section{Material and Methods}

The three vineyards were established with Merlot grapevine, clone 347, grafted on the 1103 Paulsen rootstock. Two of them were established in 2005 (vineyards 1 and 3) and the remaining vineyard was set up in 2006 (vineyard 2). Grapevines were vertical trellised and spur-pruned. The total area covered by vines was 2.42 ha.

The vine rows and 249 plants inside the vineyards were registered with a Sokkia SET 610 total station and a Sokkia GSR 2600 GPS receiver, in the way that maps of altimetry and slope were elaborated. Then, a regular network with cells of $10 \mathrm{~m} \times 10 \mathrm{~m}$ was also delineated, which was used as reference for the pedological survey and superficial soil sampling. Coordinates of four strategic points were performed with the GPS receiver, because, in this case the reception time is too long for measure of full positions. Then, the total station was used for measure distances and angles, thus, the other coordinates and altitudes were calculated. WGS 84 was used as a reference system.

Four trenches were opened for sampling soil profiles, including all horizons up to $150 \mathrm{~cm}$ deep. The soils were classified [8] according to the Brazilian System of Soil Classification [14].

Superficial soil samples were collected with a shovel cutting, near the marked vines for the Ap horizon in January, 2011: 28 samples in vineyard 1; 54 samples in vineyard 2; and 26 samples in vineyard 3.

Physical and chemical analyses were performed on the Soil Laboratory at Universidade Federal do Rio Grande do Sul (UFRGS). The following variables were evaluated: $\mathrm{pH}$; $\mathrm{Al}, \mathrm{Ca}$, $\mathrm{Na}, \mathrm{K}$, and $\mathrm{P}$ (exchangeable) contents; cationic exchangeable capacity (CEC); coarse fraction (pebbly and gravel); granulometric composition (coarse sand, fine sand, silt, clay, and flocculation degree); organic carbon; and nitrogen. Methods of soil analysis included physical separation, soft extractors for exchangeable elements, dichromate in acid media for organic C and Kjeldahl method for total N. All these methods are detailed by Embrapa [15].

Data were organized and integrated on the software ArcGIS [16] as information lawyers. Analysis of variance (ANOVA) and related procedures were processed in SPSS software [17], considering groups defined by the superficial samples of soil inside each class of soil. The semivariograms of each nutrient and the granulometric classes were processed with GS+ [18]. The spherical model adjusted the semivariograms of most of the variables, with reach of $129 \mathrm{~m}$ prevailing. $\mathrm{pH}$ and $\mathrm{Al}$ and $\mathrm{P}$ content showed nugget effect. Then, the spatial parameters were inserted on ArcGIS and kriging was applied for each variable, except for $\mathrm{Al}, \mathrm{P}$, and $\mathrm{pH}$, when the inverse distance weighted interpolation was used. 
TABLe 1: Properties of the units of soil [8]. Symbols based on Brazilian System of Soil Science (SiBCS) and correspondence SiBCS and soil taxonomy.

\begin{tabular}{|c|c|c|c|c|c|}
\hline Mapping unit & $\mathrm{SiBCS}$ & Soil taxonomy & Texture/relief/stoniness & Declivity & Area \\
\hline PBACal 1 & Argissolo & Ultisol & Moderately clayey & $3-8 \%$ & 0.13 ha \\
\hline PBACal 2 & Argissolo & Ultisol & Medium clayey to clayey, moderately wavy & $8-13 \%$ & 0.12 ha \\
\hline PBACal 3 & Argissolo & Ultisol & Clayey loam to clayey, wavy & $13-20 \%$ & $0.38 \mathrm{ha}$ \\
\hline CXve 1 & Cambissolo & Inceptisol & Clay loam to clayey & $13-20 \%$ & 0.19 ha \\
\hline CXve 2 & Cambissolo & Inceptisol & Clay loam to clayey & $20-45 \%$ & 0.47 ha \\
\hline CXve 3 & Cambissolo & Inceptisol & Clay loam to clayey, stony & $20-45 \%$ & 0.18 ha \\
\hline RRhl & Neossolo & Entisol & Sandy clay loam to loam, stony & $3-8 \%$ & 0.29 ha \\
\hline RRh 2 & Neossolo & Entisol & Sandy clay loam to loam, stony & $8-13 \%$ & 0.10 ha \\
\hline RRh 3 & Neossolo & Entisol & Sandy clay loam to loam, stony & $13-20 \%$ & 0.21 ha \\
\hline RRh 4 & Neossolo & Entisol & Sandy clay loam to loam, stony & $20-45 \%$ & 0.35 ha \\
\hline
\end{tabular}

The six nutrients ( $\mathrm{Ca}, \mathrm{C}, \mathrm{K}, \mathrm{Mg}, \mathrm{N}$, and $\mathrm{P}$ content) and the granulometric variables (clay, silt, fine sand, and coarse sand) were integrated in digital files of six and four information lawyers, respectively. Thus, unsupervised classification by maximum likelihood method was applied on each file by means of ER-Mapper [19]. Afterwards, data were edited and organized in accordance with the integrated level of enrichment of nutrients or fine fractions (clay, silt and fine sand), expressed in percentage.

A new map of management zones was elaborated by overlapping both maps mentioned before, by visual appreciation, taking into account the necessity of condensed information for industrial processes (winemaking).

\section{Results and Discussion}

3.1. Soils Survey. Soils legend discriminates three classes of soils in level of order that represent ten mapping units (Table 1). Correspondence between the Brazilian System of Soil Science (SiBCS) and Soil Taxonomy (US) is an adaptation, because Argissolo, Cambissolo, and Neossolo are considered as Entisol, Inceptisol, and Ultisol, respectively, but the terms do not have the same meaning exactly. Thus, Brazilian terms were used. The mapping units are different due to the fourth or fifth category level, mainly by Al saturation, bases saturation, texture, stony and phases of relief. These classes occupied $26.03 \%, 34.71 \%$, and $39.26 \%$ of the total area of the three vineyards, respectively.

The spatial distribution of the units of soil is represented in Figure 1. The image of satellite in background show direction $\mathrm{E}-\mathrm{W}$ for vines in the vineyards 1 and 2, but direction of vine lines is N-S for vineyard 3.

Mapping units PBACal refer to soils with textural B horizon, immediately below A horizon in this case, with high content of clay, grayish brown color, and Al enrichment in several horizons (Table 2), thus with alic condition. The profiles 2 and 4 (PBACal) were studied up to $1.5 \mathrm{~m}$ deep, with enrichment in Ap horizon for bases content, organic $\mathrm{C}, \mathrm{N}$, and $\mathrm{P}$, as well as differences in declivity and texture (Table 1). BC horizon is intermediary between a B horizon and a $\mathrm{C}$ horizon, but with prevalent materials from $\mathrm{B}$ horizon. Abrupt condition of units PBACal 2 and PBACal 3 refers to the occurrence of high content of clay in B horizon, deriving on strong differentiation between horizons A and B.

Each class of soil showed different sequence of horizons, but Ap horizon, a superior A horizon plow or removed, occurred in all cases. Mapping unit RRh 4 of Neossolo is in accordance with Ap1 and Ap2. Argissolo (PBACal,) have a subdivision for $\mathrm{B}$ horizon in deep, with accumulation of clay (Bt1 and Bt2). Cambissolo (CXve 3,) has an intermediary horizon $\mathrm{AB}$ and in sequence, an incipient $\mathrm{B}$ horizon $(\mathrm{Bi})$ and a BC horizon. PBACal 2 and 3 units have abruptic condition due to the occurrence of more clay in B horizon than in $\mathrm{A}$ horizon, with strong contrast between these two horizons.

From a physicochemical point of view, Cambissolo and Argissolo are different between them, mainly for Al saturation, bases content and clay content (Table 2). These soils had greater organic matter than Neossolo, with significant gravel in this case. About declivity, Argissolo ranged from 3\% to $20 \%$, Cambissolo ranged from $13 \%$ to $45 \%$, and Neossolo ranged from $3 \%$ to $45 \%$, this one with the greatest variation. This feature, associated with texture, affects significantly the dynamic of water circulation through the different edaphic horizons.

High contents of $\mathrm{Cu}, \mathrm{Mn}, \mathrm{P}$, and $\mathrm{Zn}$ in the superficial horizons of the three classes of soils, when compared to the subsuperficial horizons, suggest a strong influence of the local viticulture management.

Water storage capacity (WSC) was different for each horizon and profile, suggesting strong dependence with climate. For instance, CXve3, PBACal2, and PBACall have good storage capacity for subsuperficial horizons, but RRha does not show a good storage capacity. So, vines production may be impaired for dry climate in the case of RRha; contrariwise, production may be improved for wet climate. An opposite situation can happen for the remained soils.

\subsection{Superficial Soil Data Processing}

3.2.1. Statistical Analysis of Superficial Soil Data. Variables with variation coefficients greater than $50 \%$ presented almost the total population near of the minimum values, but with some high extreme values in the case of pebbly and level of $\mathrm{Al}$. However, when the variation coefficients ranged between 


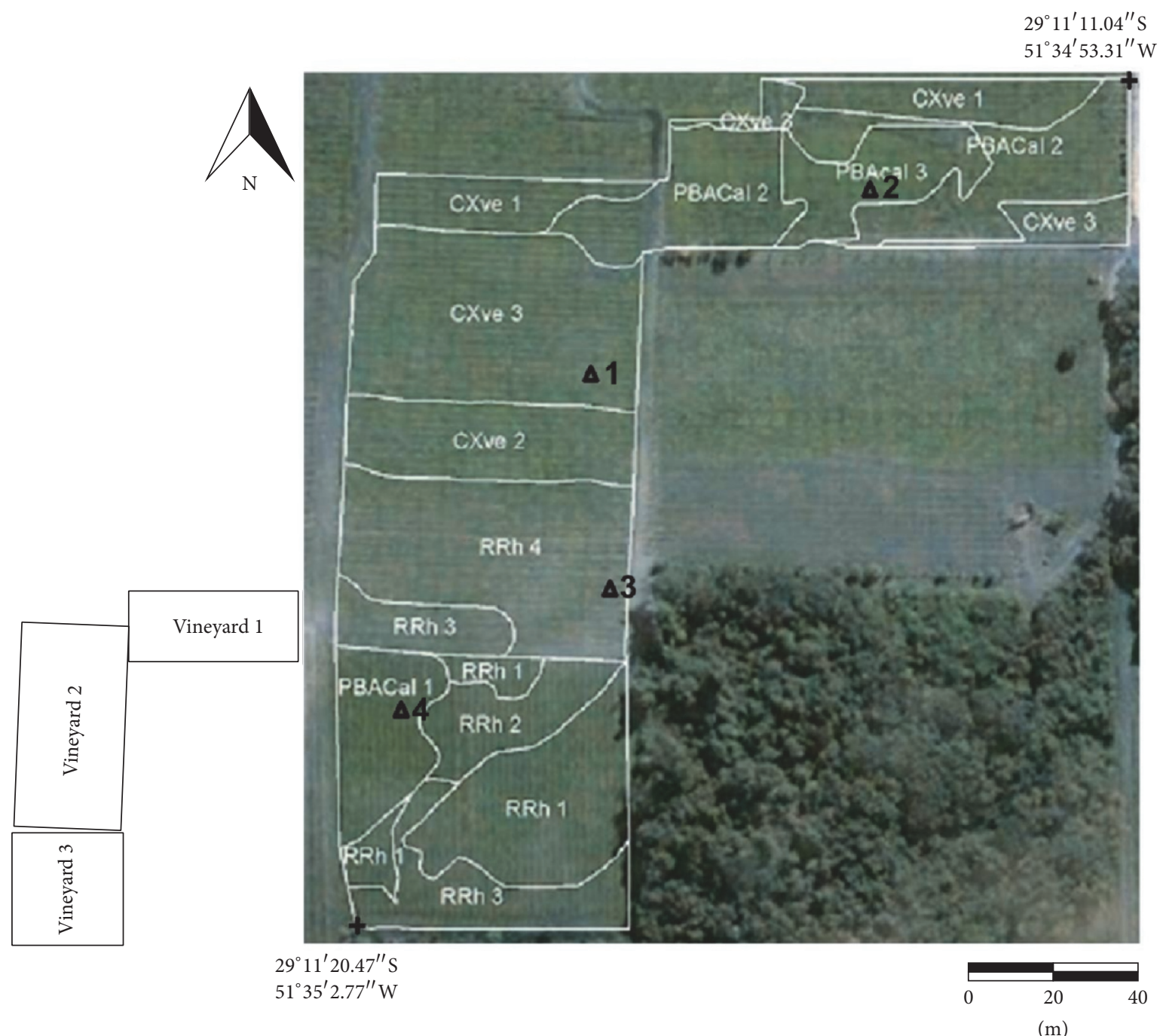

FIGURE 1: Map of soils of the study area on the orbital image as background (Google Earth $\left.{ }^{\circledR}, 2013\right)$. Triangles indicate the location of the soil profiles.

$30 \%$ and $35 \%$, the mean located near the half of the range of variation (Table 3 ).

Statistics were processed for each class of soil including homogeneity and analysis of variance or ANOVA (Table 4). All variables showed significance lesser than $15 \%$ for variance homogeneity test with the exception of coarse sand and $\mathrm{pH}$. Thus, precision of ANOVA test would be affected by both variables. Anyway, all variables were significant for ANOVA test at level of 5\%, so, in general terms, at least one mean of the classes of soils is different to the other ones.

Variation of the means is represented by line graphs (Figure 2). Main variations occur among classes of soil (Argissolo, Cambissolo, and Neossolo); however softer variations happen within the classes, suggesting declivity differences or degree of stoniness because these two parameters affected differences among classes.

3.2.2. Geospatial Analysis of Superficial Soil Data. Semivariograms were adjusted mostly by the spherical model and the predominant reach was $129 \mathrm{~m}$. The spatial distribution of the granulometric variables (clay, silt, fine sand and coarse sand) in the Ap horizon is shown in Figure 3. A sudden transition from vineyard 2 to vineyard 3 is observed for clay, silt and fine sand, thus, result of soil map is confirmed (Figure 1). Separation between Cambissolo and Neossolo in vineyard 2 also appears in Figure 3, as well as the high clay content related to Argissolo.

Spatial distribution of nutrients $(\mathrm{Ca}, \mathrm{C}, \mathrm{K}, \mathrm{Mg}, \mathrm{N}$, and $\mathrm{P}$ ) in the vineyards 1, 2, and 3 is showed in Figures 4, 5, and 6, respectively. $\mathrm{P}$ was constant in vineyard 1 and $\mathrm{C}$ and $\mathrm{N}$ were very similar in the three vineyards. The greatest variability for $\mathrm{C}, \mathrm{Ca}, \mathrm{Mg}, \mathrm{N}$, and $\mathrm{P}$ was associated with vineyard 3.

Observation of the means of each class of soil (Figure 2) in comparison to the geospatial distribution of granulometric fractions (Figure 3) and level of chemical elements (Figures 4, 5 and 6) suggest a coherent adjustment between both procedures of processing data. 
TABLE 2: Physical and chemical parameters of the soil profiles for each horizon.

\begin{tabular}{|c|c|c|c|c|c|c|c|c|c|c|c|c|c|c|c|}
\hline \multirow[b]{2}{*}{ Horizonte } & \multicolumn{4}{|c|}{ CXve 3 (profile 1) } & \multicolumn{4}{|c|}{ PBACal 2 (profile 2) } & \multicolumn{4}{|c|}{ PBACal 1 (profile 4) } & \multicolumn{3}{|c|}{ RRha (profile 3) } \\
\hline & Ap & $\mathrm{AB}$ & $\mathrm{Bi}$ & $\mathrm{BC}$ & Ap & Bt1 & Bt2 & $\mathrm{BC}$ & Ap & Bt1 & Bt2 & $\mathrm{BC}$ & Alp & $\mathrm{A} 2$ & $\mathrm{CR}$ \\
\hline Thickness (cm) & 14 & 21 & 40 & 80 & 24 & 18 & 37 & 71 & 15 & 16 & 48 & 71 & 25 & 36 & 109 \\
\hline $\mathrm{Ca}\left(\mathrm{cmol}_{\mathrm{c}} / \mathrm{kg}^{-1}\right)$ & 13.6 & 6.1 & 8 & 6.4 & 6.3 & 3 & 1.9 & 1.8 & 10 & 3.7 & 2.9 & 1.5 & 11.1 & 12.9 & 3.1 \\
\hline $\operatorname{Mg}\left(\mathrm{cmol}_{\mathrm{c}} / \mathrm{kg}^{-1}\right)$ & 3.1 & 1.9 & 3.9 & 4.5 & 1.1 & 1.3 & 0.9 & 1 & 3.9 & 2 & 0.9 & 0.8 & 2.7 & 4.1 & 1 \\
\hline $\mathrm{K}\left(\mathrm{cmol}_{\mathrm{c}} \cdot \mathrm{kg}^{-1}\right)$ & 0.8 & 0.3 & 0.3 & 0.5 & 0.3 & 0.2 & 0.2 & 0.3 & 5 & 2 & 2 & 2 & 0.7 & 1.5 & 1.3 \\
\hline Organic C $\left(\mathrm{g} \cdot \mathrm{kg}^{-1}\right)$ & 27 & 7 & 6 & 3.7 & 16 & 13 & 8 & 5.8 & 23 & 12 & 10 & 5.2 & 16 & 15 & 4.9 \\
\hline $\mathrm{N}\left(\mathrm{g} \cdot \mathrm{Kg}^{-1}\right)$ & 2.3 & 0.7 & 0.6 & 0.4 & 1.3 & 1.1 & 0.7 & 0.6 & 2.1 & 1.2 & 1 & 0.5 & 1.6 & 1.5 & 0.5 \\
\hline $\mathrm{CEC}\left(\mathrm{cmol}_{\mathrm{c}} / \mathrm{kg}\right)$ & 21 & 11 & 16 & 30 & 12 & 12 & 11 & 10 & 18 & 11 & 13 & 12 & 18 & 20 & 13 \\
\hline Bases saturation (\%) & 83 & 76 & 79 & 38 & 66 & 36 & 27 & 31 & 78 & 51 & 30 & 21 & 80 & 87 & 33 \\
\hline Sum of bases $\left(\mathrm{cmol}_{\mathrm{c}} / \mathrm{kg}\right)$ & 17 & 8 & 13 & 11 & 8 & 4 & 3 & 3 & 14 & 6 & 4 & 2 & 15 & 17 & 4 \\
\hline $\mathrm{P}(\mathrm{mg} / \mathrm{kg})$ & 67 & 9 & 7 & 8 & 20 & 8 & 8 & 7 & 52 & 12 & 9 & 13 & 74 & 64 & 15 \\
\hline $\mathrm{pH}$ in water & 6.0 & 6.0 & 5.8 & 5.0 & 5.4 & 5.0 & 4.8 & 4.8 & 5.5 & 5.3 & 4.8 & 4.7 & 6.3 & 6.0 & 4.7 \\
\hline $\mathrm{Al}$ exch. $\left(\mathrm{cmol}_{\mathrm{c}} / \mathrm{kg}\right)$ & 0 & 0 & 0 & 11 & 0.2 & 3 & 4 & 3 & 0.4 & 1 & 5 & 7 & 0 & 0 & 7 \\
\hline Al saturation (\%) & 0 & 0 & 0 & 58 & 3 & 42 & 59 & 52 & 3 & 14 & 56 & 75 & 0 & 0 & 63 \\
\hline Gravel $\left(\mathrm{g} \cdot \mathrm{kg}^{-1}\right)$ & 10 & 0 & 0 & 0 & 0 & 0 & 10 & 0 & 0 & 0 & 20 & 60 & 200 & 230 & 250 \\
\hline Clay $\left(\mathrm{g} \cdot \mathrm{kg}^{-1}\right)$ & 400 & 470 & 520 & 610 & 360 & 610 & 590 & 570 & 410 & 460 & 570 & 420 & 260 & 220 & 220 \\
\hline Silt $\left(\mathrm{g} \cdot \mathrm{kg}^{-1}\right)$ & 250 & 200 & 190 & 60 & 310 & 210 & 230 & 220 & 370 & 360 & 290 & 220 & 250 & 310 & 190 \\
\hline Fine sand $\left(\mathrm{g} \cdot \mathrm{kg}^{-1}\right)$ & 100 & 90 & 110 & 140 & 90 & 50 & 50 & 60 & 70 & 70 & 50 & 110 & 140 & 150 & 110 \\
\hline Coarse sand $\left(\mathrm{g} \cdot \mathrm{kg}^{-1}\right)$ & 250 & 240 & 180 & 190 & 240 & 130 & 130 & 150 & 150 & 110 & 90 & 250 & 350 & 320 & 480 \\
\hline Soil density & 1.15 & 1.1 & 1.1 & 1.12 & 1.32 & 1.3 & 1.4 & 1.4 & 1.1 & 1.2 & 1.2 & 1.1 & 1.0 & 1.1 & nd \\
\hline WSC (mm) & 5.3 & 6.9 & 17.6 & 17.9 & 12.7 & 4.7 & 9.2 & 19.9 & 6.8 & 9.9 & 22 & 15.1 & 7.9 & 7.5 & nd \\
\hline $\mathrm{S}\left(\mathrm{mg} / \mathrm{dm}^{3}\right)$ & 6 & 2 & 2 & 12 & 4 & 21 & 20 & 13 & 10 & 15 & 47 & 42 & 70 & 4 & 22 \\
\hline $\mathrm{Zn}\left(\mathrm{mg} / \mathrm{dm}^{3}\right)$ & 41 & 3 & 0.4 & 1 & 13 & 1 & 1 & 1 & 27 & 3 & 1 & 2 & 14 & 15 & 0.4 \\
\hline $\mathrm{Cu}\left(\mathrm{mg} / \mathrm{dm}^{3}\right)$ & 351 & 18 & 3 & 3 & 123 & 4 & 3 & 4 & 110 & 10 & 5 & 3 & 97 & 105 & 1 \\
\hline $\mathrm{B}\left(\mathrm{mg} / \mathrm{dm}^{3}\right)$ & 0.5 & 0.3 & 0.3 & 0.2 & 0.4 & 0.1 & 0.2 & 0.1 & 0.7 & 1.3 & 1.4 & 0.3 & 0.4 & 0.6 & 0.4 \\
\hline $\mathrm{Mn}\left(\mathrm{mg} / \mathrm{dm}^{3}\right)$ & 55 & 19 & 11 & 6 & 45 & 19 & 14 & 13 & 57 & 25 & 6 & 4 & 40 & 25 & 16 \\
\hline
\end{tabular}

$\mathrm{CEC}=$ capacity for exchangeable cations; $\mathrm{WSC}=$ water storage capacity.

TABLE 3: Statistics for variables related to the 108 soil samples (Ap horizon).

\begin{tabular}{|c|c|c|c|c|}
\hline Variable & Unit & Mean & Range & VC (\%) \\
\hline Pebbly (>20 mm) & $\mathrm{g} \cdot \mathrm{kg}^{-1}$ & 50 & $0-270$ & 132 \\
\hline Gravel $(2-20 \mathrm{~mm})$ & $\mathrm{g} \cdot \mathrm{kg}^{-1}$ & 160 & $0-410$ & 69 \\
\hline Fine land $(<2 \mathrm{~mm})$ & $\mathrm{g} \cdot \mathrm{kg}^{-1}$ & 790 & $480-1000$ & 17 \\
\hline $\mathrm{C}($ organic $)$ & $\mathrm{g} \cdot \mathrm{kg}^{-1}$ & 20 & $8-46$ & 32 \\
\hline $\mathrm{N}$ & $\mathrm{g} \cdot \mathrm{kg}^{-1}$ & 2 & $0.5-4.4$ & 34 \\
\hline pH (in water) & & 6 & $5-7.4$ & 7 \\
\hline $\mathrm{Al}$ & cmolc $\cdot \mathrm{kg}^{-1}$ & 0.01 & $0-0.5$ & 441 \\
\hline $\mathrm{Ca}$ & $\mathrm{cmolc} \cdot \mathrm{kg}^{-1}$ & 11 & $4-23$ & 32 \\
\hline $\mathrm{Mg}$ & cmolc $\cdot \mathrm{kg}^{-1}$ & 2.4 & $1.2-4.5$ & 31 \\
\hline $\mathrm{K}$ & cmolc $\cdot \mathrm{kg}^{-1}$ & 0.6 & $0.1-1.1$ & 34 \\
\hline $\mathrm{P}$ & cmolc $\cdot \mathrm{kg}^{-1}$ & 86 & $9-423$ & 85 \\
\hline Bases saturation & $\%$ & 76 & $29-97$ & 17 \\
\hline
\end{tabular}

$\mathrm{VC}=$ variation coefficient (standard deviation expressed as percentage of the mean). 
TABLE 4: Results of ANOVA as a factor of soil classes. LS = Levene statistic; $S_{\mathrm{HV}}=$ significance of homogeneity of variances test, $\%$; $S_{\mathrm{A}}$ $=$ significance of $F$ statistic, \% (ANOVA). Number of samples for the classes of soils and total: CXve1, CXve2, CXve3, PBAcal1, PBAcal2, PBAcal3, RRh1, RRh2, RRh3, and RRh4 and total equal to 8, 10, 22, 6, 15, 7, 11, 4, 8, 17, and 108, respectively.

\begin{tabular}{|c|c|c|c|c|c|c|}
\hline Variable & Units & Extreme means & LS & $S_{\mathrm{HV}}$ & $F$ & $S_{\mathrm{A}}$ \\
\hline Coarse sand & $\mathrm{g} \cdot \mathrm{kg}^{-1}$ & $180-340$ & 1.43 & 18.5 & 4.94 & 0.0 \\
\hline Fine sand & $\mathrm{g} \cdot \mathrm{kg}^{-1}$ & $73-139$ & 1.64 & 11.3 & 13.96 & 0.0 \\
\hline Silt & $\mathrm{g} \cdot \mathrm{kg}^{-1}$ & $206-370$ & 1.61 & 12.2 & 3.77 & 0.0 \\
\hline Clay & $\mathrm{g} \cdot \mathrm{kg}^{-1}$ & $222-479$ & 1.56 & 13.7 & 5.25 & 0.0 \\
\hline C organic & $\mathrm{g} \cdot \mathrm{kg}^{-1}$ & $15-30$ & 3.06 & 0.3 & 7.08 & 0.0 \\
\hline $\mathrm{N}$ & $\mathrm{g} \cdot \mathrm{kg}^{-1}$ & $1,4-3$ & 2.09 & 3.7 & 8.39 & 0.0 \\
\hline $\mathrm{pH}$ & & $5,7-6,6$ & 1.14 & 34.4 & 5.09 & 0.0 \\
\hline $\mathrm{Ca}$ & $\mathrm{cmol}_{\mathrm{c}} \cdot \mathrm{kg}^{-1}$ & $7-15,4$ & 7.25 & 0.0 & 10.37 & 0.0 \\
\hline $\mathrm{Mg}$ & $\mathrm{cmol}_{\mathrm{c}} \cdot \mathrm{kg}^{-1}$ & $1,5-3,5$ & 2.99 & 0.3 & 14.00 & 0.0 \\
\hline K & $\mathrm{cmol}_{\mathrm{c}} \cdot \mathrm{kg}^{-1}$ & $0,36-0,74$ & 1.61 & 12.2 & 7.03 & 0.0 \\
\hline $\mathrm{P}$ & $\mathrm{cmol}_{\mathrm{c}} \cdot \mathrm{kg}^{-1}$ & $35-127$ & 2.16 & 3.2 & 2.89 & 0.5 \\
\hline CEC & $\mathrm{cmol}_{\mathrm{c}} \cdot \mathrm{kg}^{-1}$ & $9-20$ & 7.00 & 0.0 & 12.10 & 0.0 \\
\hline Bases saturation & $\%$ & $63-86$ & 3.93 & 0.0 & 3.36 & 0.1 \\
\hline
\end{tabular}

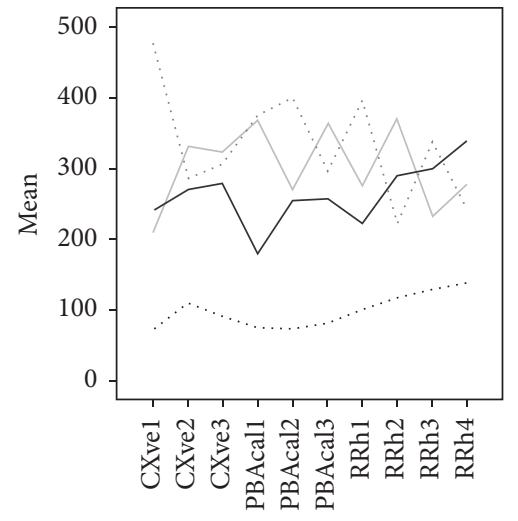

Class of soil

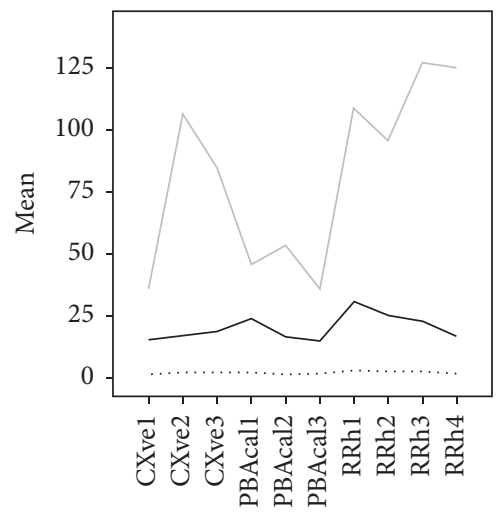

Class of soil

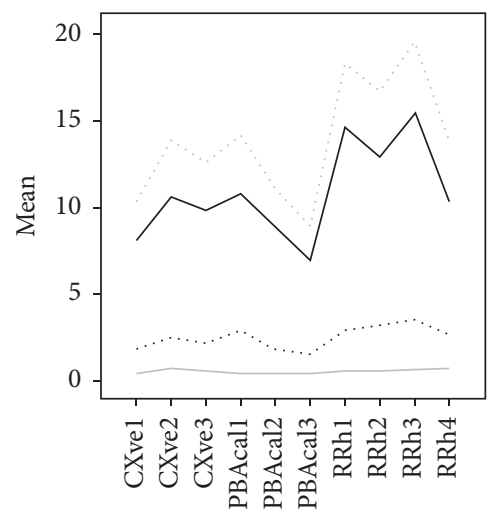

Class of soil

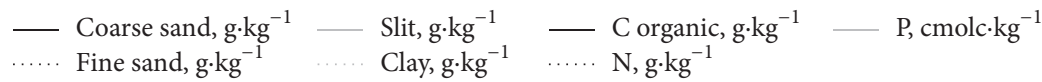

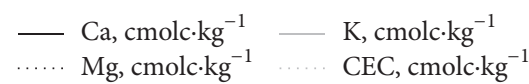

Figure 2: The linear graphs show the variation of the mean related to each class of soil for different variables.

3.3. Data Integration of Geospatial Data. Map of integrated granulometric variables in Ap horizon overlapped partially conventional map of soils (Figure 7). Vineyard 1 was divided into two parts in direction E-W, with local variations, perhaps related to transition among edaphic units. A spot with content of clay + silt + fine sand from 700 to $750 \mathrm{~g} \cdot \mathrm{kg}^{-1}$ in vineyard 2 may be associated with Cambissolos (CXve1, CXve2, and CXve3) and the transition to Neossolo (RRha), with diagonal geometry suggesting the influence of slope, very strong in this zone. Argissolo was well characterized in vineyard 3 but the same did not happen to Neossolos (RRh1, RRh2, and RRh3).

The western part of vineyard 1 and the northern part of vineyard 2 showed similar spatial distribution of low values of nutrient content in Ap horizon (Figure 8). Then, a moderate zone in nutrient content was established, including the northern half of vineyard 3. The remaining half of vineyard 3 showed significant increase in nutrient content, mainly organic matter, $\mathrm{Ca}$ and $\mathrm{Mg}$. According to the present land use, there is a woodland on the lateral part of the vineyard 3 (Figure 1), then perhaps part of the wood was removed before grapevines were cultivated. This may explain increase in organic matter but enrichment of alkaline earth elements seems to be associated with fertilization.

The map management zones (Figure 9) was elaborated by overlapping the maps of Figures 7 and 8 . This map and previous maps $[9,10]$ were elaborated with different methods or based on different variables, but final result is similar. Conventional soil maps evaluate circulation of water and nutrients to all horizons, usually up to 1.5-2.0 $\mathrm{m}$ deep, evolving subsuperficial variability. On the other hand, the maps based on superficial sampling (Ap horizon) do not include that dimension but a significant analysis of horizontal variability.

3.4. Final Remarks. Pedological maps and superficial soil maps overlap partially, perhaps due to their complementary 


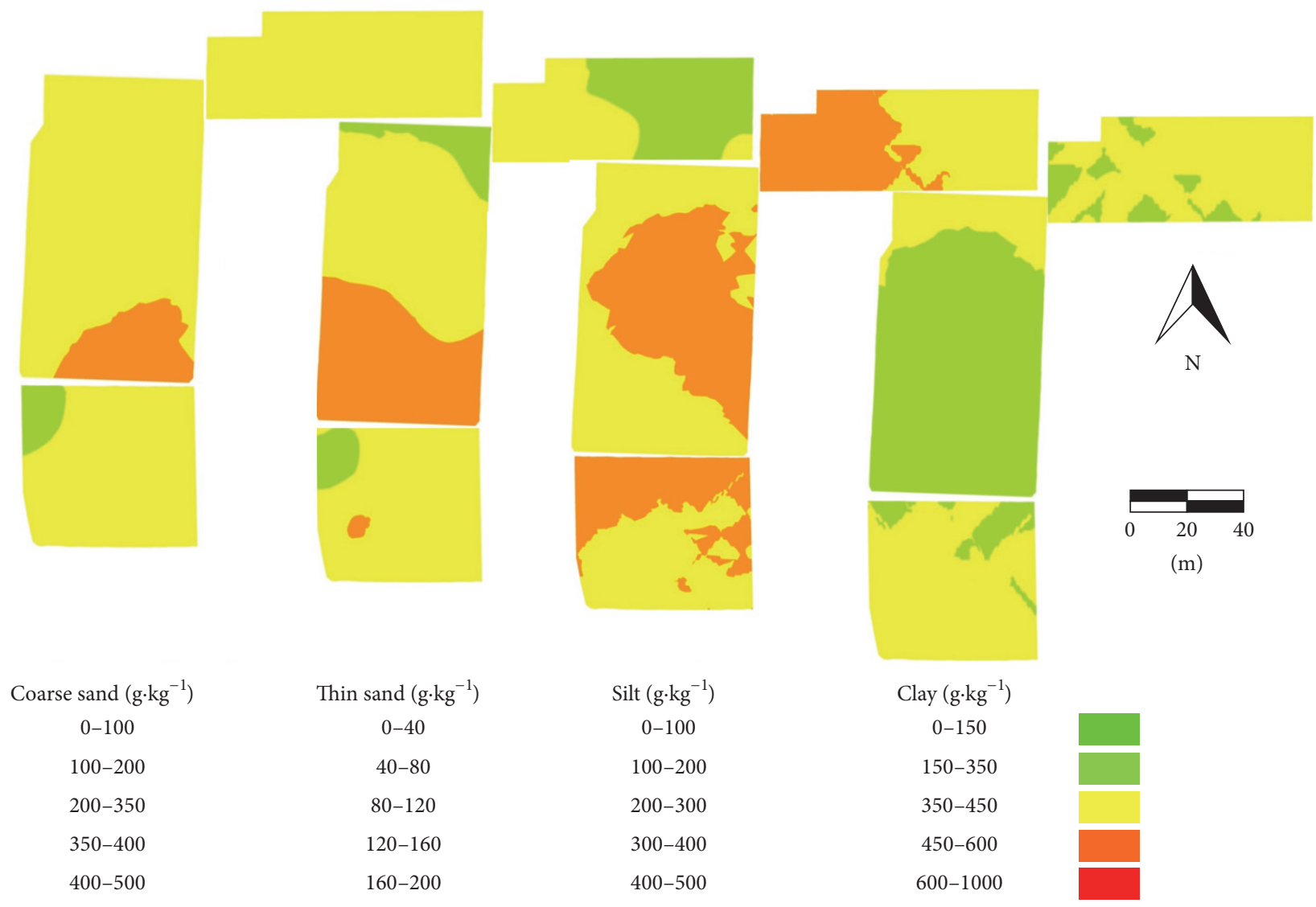

FIgURE 3: Spatial distribution of granulometric variables related to Ap horizon in the study area.
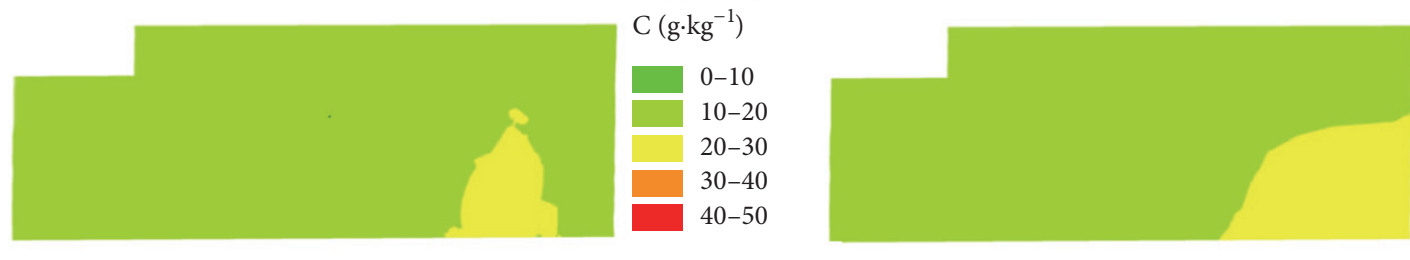

$\mathrm{Ca}\left(\mathrm{cmolc} \cdot \mathrm{kg}^{-1}\right)$
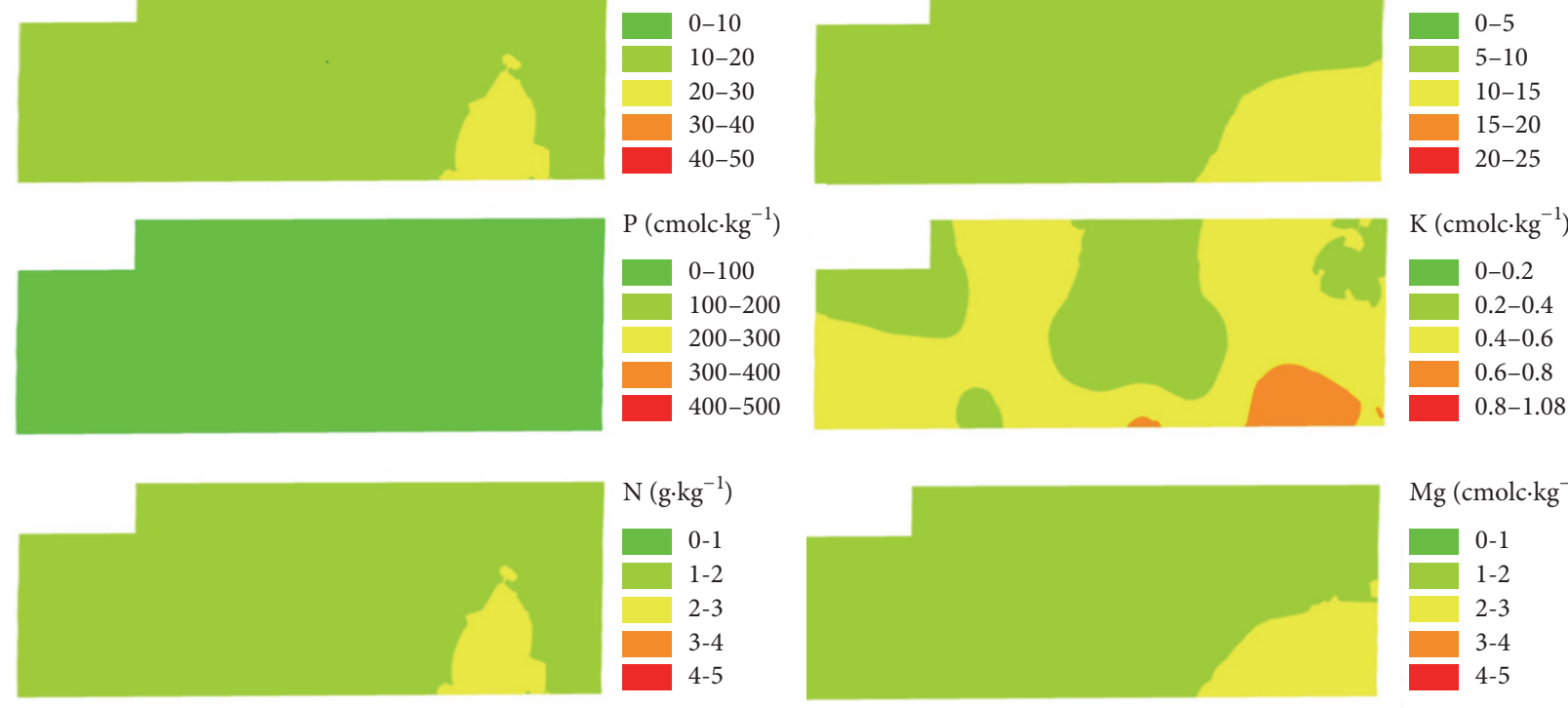

$\mathrm{K}\left(\mathrm{cmolc} \cdot \mathrm{kg}^{-1}\right)$

$0-0.2$

$0.2-0.4$

$0.4-0.6$

$0.6-0.8$

$0.8-1.08$

FIGURE 4: Spatial distribution of nutrients in the soils of vineyard 1 (horizon Ap). 


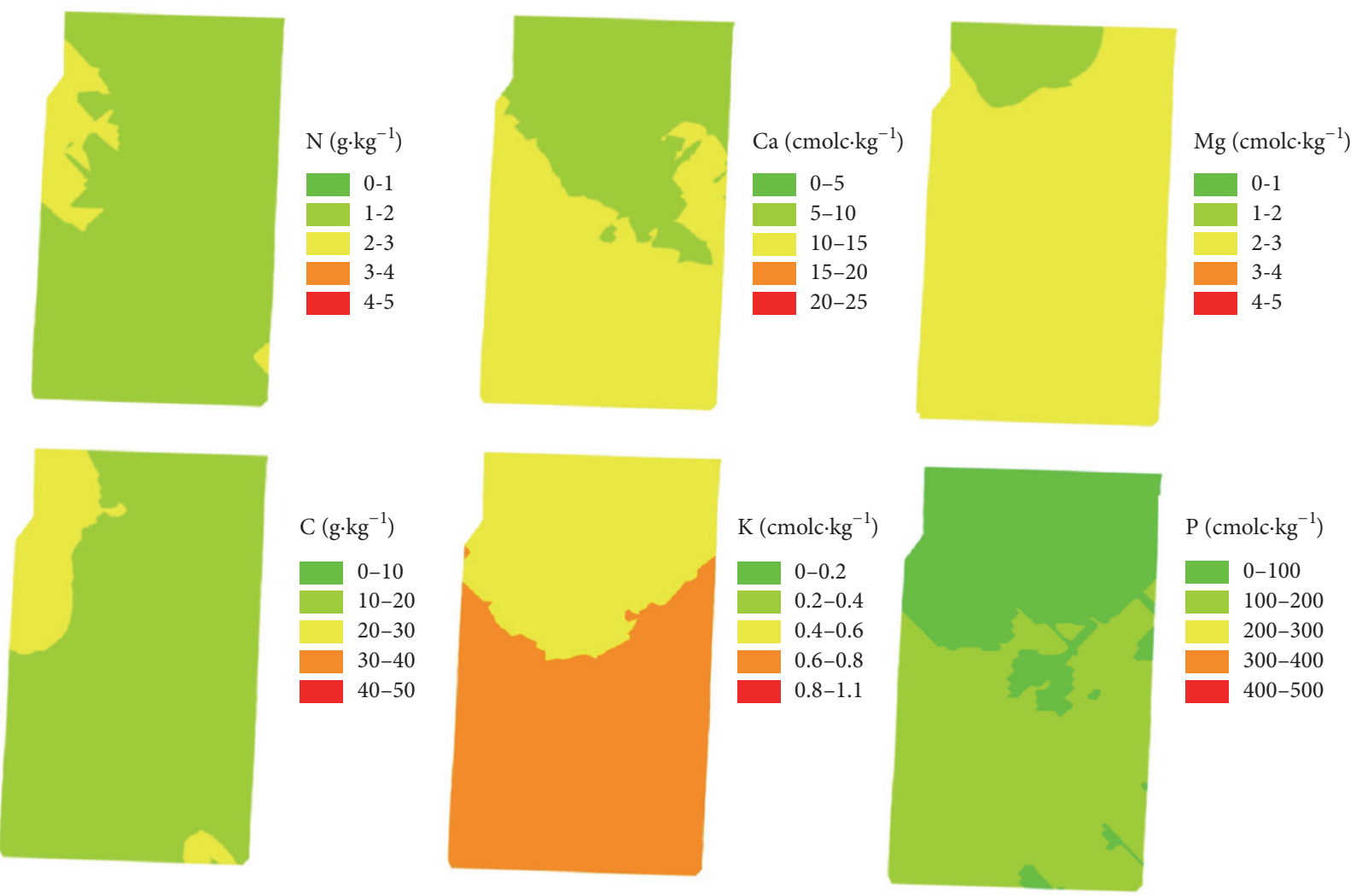

FIgURE 5: Spatial distribution of nutrients in the soils of vineyard 2 (horizon Ap).
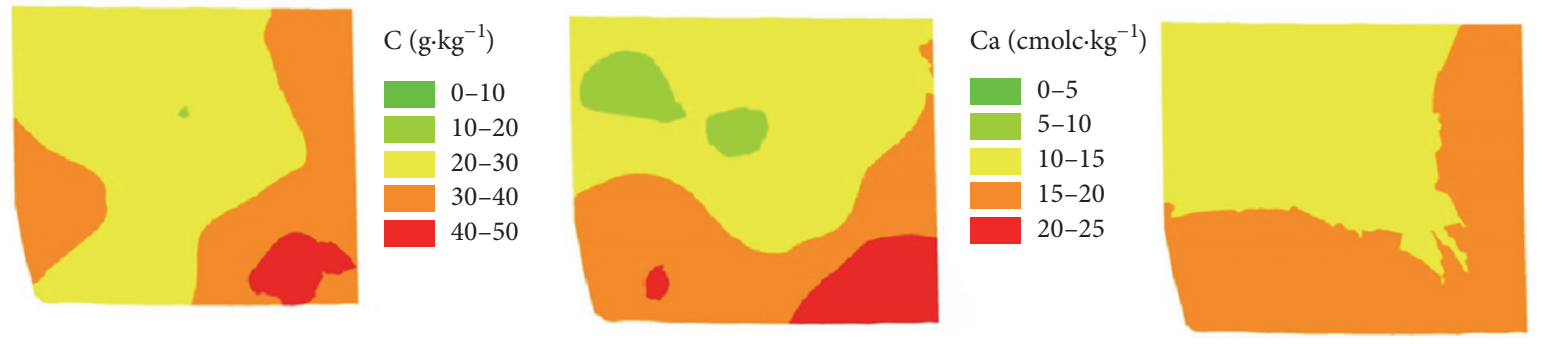

$\mathrm{K}\left(\mathrm{cmolc} \cdot \mathrm{kg}^{-1}\right)$
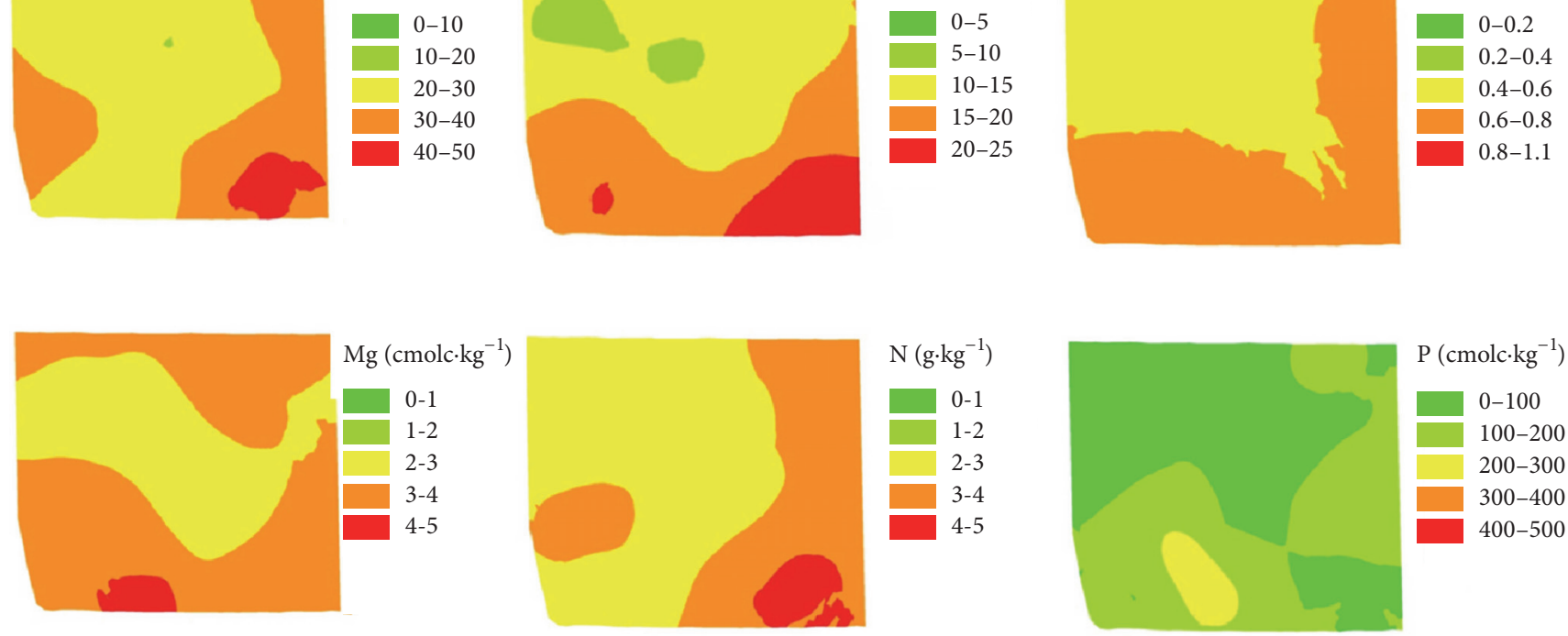

$\mathrm{P}\left(\mathrm{cmolc} \cdot \mathrm{kg}^{-1}\right)$

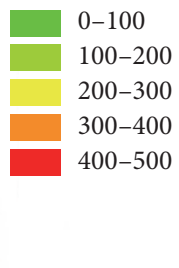

FIGURE 6: Spatial distribution of nutrients in the soils of vineyard 3 (horizon Ap). 


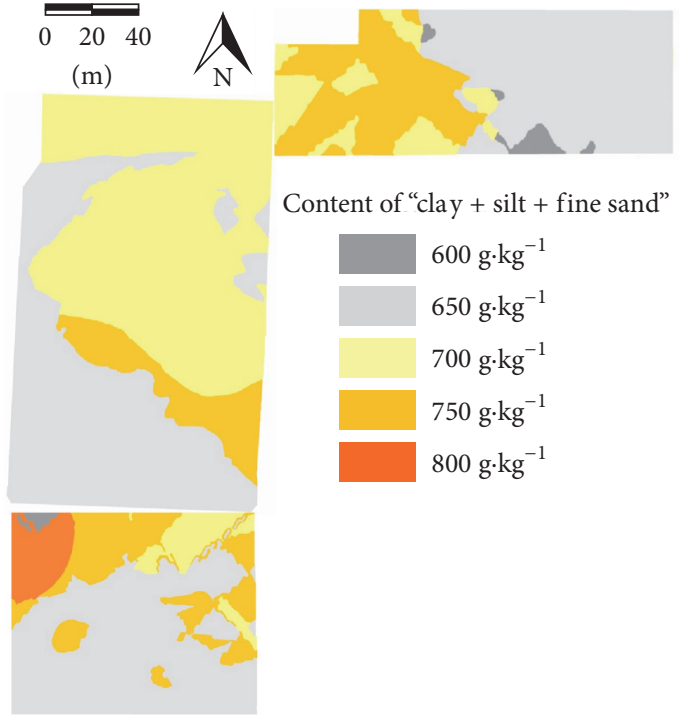

FIGURE 7: Spatial distribution of the content of fine minerals (clay, silt, and fine sand) in Ap horizon for the study area.

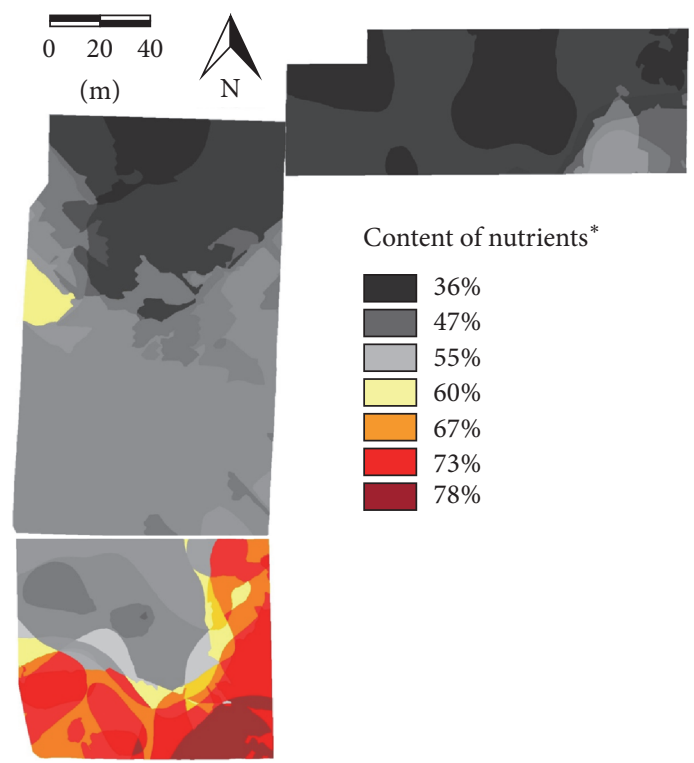

FIGURE 8: Spatial distribution of the content of nutrients (C, Ca, K, $\mathrm{Mg}, \mathrm{N}$, and $\mathrm{P})$ in Ap horizon for the study area. ${ }^{*} \mathrm{C}+\mathrm{Ca}+\mathrm{K}+\mathrm{Mg}$ $+\mathrm{N}+\mathrm{P}$.

nature but not substitutive. Management zones can be defined by means of the pedological map or when several information lawyers are integrated. Anyway, this and previous works $[9,10]$ pointed that different methods resulted in similar management zones but with local differences.

Perhaps, an integration of information lawyers, from an PA perspective, would be more efficient way to define management zones. However, the ideal set of variables must be found.

Addressing the specific questions mentioned in the introduction of this paper.

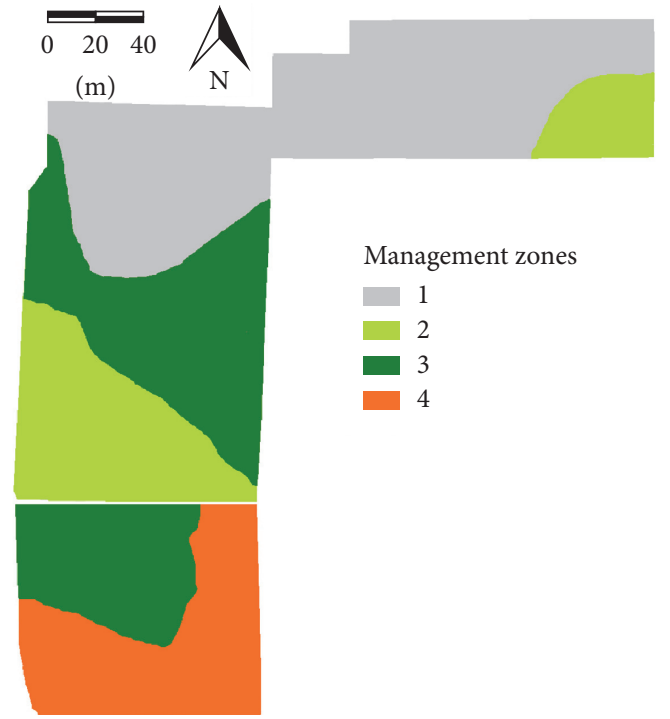

FIGURE 9: Management zones defined by integration of ten variables (granulometry and nutrients). 1: moderate CSS and low CN; 2: low CSS and moderate CN; 3: moderate CSS and moderate CN; 4: moderate CSS and high CN. CSS = content of clay + silt + fine sand; $\mathrm{CN}=$ content of nutrients.

(1) Soil Mapping Is an Expensive Procedure, Costly, and Time Consuming; Is There Some Other Technique with the Same Level of Efficiency and Cheaper? Several authors mentioned the influence of soil depth on grape quality; however the type of soil would not be an affecting factor in that sense. Some results of the present work suggest the influence of declivity that altogether with soil depth and other parameters control the water cycle of soil, therefore, the relation between soil and grapevines.

Hence, geotechnologies represent exceptional tools to support precision agriculture, improving the knowledge of the horizontal variability obtained from soil research, but a vertical component must be incorporated. The superficial sampling of soil must be complemented with a digital elevation model and the study of depth of soil and texture of subsuperficial horizons. In that sense, studies on apparent electrical conductivity represent a good option, since, data in two depths are supplied [20].

(2) Geospatial Analysis and GIS Procedures Are Related to PA, but Standard Procedures for Interpolation and Fusion Data Are Generally Absent of Bibliographies. A Specific Method in That Sense Is Presented and Discussed Here. A method of fusion data was used, including geostatistical processing and unsupervised classification of nutrient data and texture data. A final map of management zones was constructed by observation and synthesis. There was coincidence with previous management zones $[9,10]$, but local differences and variations from each methodology were observed. Correlation between the management zone map produced by this work and the conventional soil map [8] was weak in that sense. Management zones must be conferred according to grapes quality or derived wines, but in this work only the 
edaphic parameters were considered. Consequently, a new challenge will be the integration of these other kinds of data with information discussed here.

(3) How Are Soil Units Related to Viticulture Variables? Shallow soils provide few water and nitrogen to vines. Consequently, the yield of the vineyard is reduced and the quality of berries is improved. In the present study, this situation was corroborated by Neossolo RRh 4, which occurred with scarce depth (Table 2). A similar status would be expected for units RRh 1 and RRh 3; nevertheless, they had high levels of nutrients, as explained before.

\section{Competing Interests}

The authors declare that they have no competing interests.

\section{Acknowledgments}

The authors are thankful to Miolo Winery for making its vineyards available to carry out this research and to $\mathrm{CNPq}$ for providing part of resources.

\section{References}

[1] E. Tayari, A. R. Jamshid, and H. R. Goodarzi, "Role of GPS and GIS in precision agriculture," Journal of Scientific Research and Development, vol. 2, no. 3, pp. 157-162, 2015.

[2] T. Proffitt, R. Bramley, D. Lamb, and E. Winter, Precision Viticulture: A New Era in Vineyard Management and Wine Production, Winetitles, Adelaide, Australia, 2006.

[3] A. McBratney, B. Whelan, T. Ancev, and J. Bouma, "Future directions of precision agriculture," Precision Agriculture, vol. 6, no. 1, pp. 7-23, 2005.

[4] European Parliament, Precision Agriculture: An Opportunity for EU Farmers-Potential Support with the Cap 2014-2020, IP/B/AGRI/IC?2013_153, 2014.

[5] A. McBratney, M. Mendonça Santos, and B. Minasny, "On digital soil mapping," Geoderma, vol. 117, no. 1-2, pp. 3-52, 2003.

[6] B. Minasny and A. B. Bratney, "Methodologies for global soil mapping," in Digital Soil Mapping: Bridging Research, Environmental Application, and Operation, J. L. Boettinger, D. W. Howell, A. C. Moore, A. E. Hartemink, and S. Kienast-Brown, Eds., vol. 2 of Progress in Soil Science, pp. 429-436, Springer, Berlin, Germany, 2010.

[7] V. C. Leeuwen, J. P. Roby, D. Pernet, and B. Bois, "Methodology of soil based zoning for viticultural terrois," Bulletin de l'OIV, vol. 83, no. 947, pp. 13-29, 2010.

[8] C. A. Flores, J. M. Filippini-Alba, H. F. Levien, D. H. Zarnott, A. Miele, and C. Pavan, "Levantamento detalhado dos solos e a viticultura de precisão," in Anais do XXXIII Congresso Brasileiro de Ciência do Solo, Sociedade Brasileira de Ciência do Solo, Uberlândia, Brazil, 2011.

[9] J. M. Filippini-Alba, C. A. Flores, A. Miele, and L. M. Villani, "SIG para a gestão vitivinícola no Vale dos Vinhedos, RS," in Agricultura de Precisão: Resultados de um Novo Olhar, A. C. Bernardi, J. M. Naime, A. V. Resende, L. H. Bassoi, and R. Y. Inamasu, Eds., pp. 368-373, Embrapa, Brasília, Brazil, 2014.

[10] J. M. Filippini-Alba, C. A. Flores, and A. Miele, "Modelagem espacial do solo para apoio à viticultura de precisão: Vale dos Vinhedos, Serra Gaúcha, Rio Grande do Sul, Brasil," Revista
Brasileira de Viticultura e Enologia, Bento Gonçalves, no. 4, pp. 8-17, 2012.

[11] A. Miele, C. A. Flores, and J. M. Filippini-Alba, "Efeito do tipo de solo nos compostos fenólicos e na atividade antioxidante do vinho," Revista Brasileira de Viticultura e Enologia, no. 6, pp. 4047, 2014.

[12] G. Chavarria, H. Bergamaschi, L. C. da Silva et al., "Relações hídricas, rendimento e compostos fenólicos de uvas Cabernet Sauvignon em três tipos de solo," Bragantia, vol. 70, no. 3, pp. 481-487, 2011.

[13] J. Coipel, R. B. Lovelle, C. Sipp, and C. van Leeuwen, “'Terroir” effect, as a result of enviromental stess, depends more on soil depth than on soil type (Vitis vinifera L. cv. Grenache Noir, Côtes du Rhône, France, 2000)," Journal International des Sciences de la Vigne et du Vin, vol. 40, no. 4, pp. 177-185, 2006.

[14] H. G. Santos, P. K. T. Jacomine, L. H. C. dos Anjos et al., Eds., Sistema Brasileiro de Classificação de Solos, Embrapa Solos, Rio de Janeiro, Brazil, 2006.

[15] Embrapa, Manual de Métodos de Análise de Solo, Embrapa Solos, Rio de Janeiro, Brazil, 2nd edition, 1997.

[16] ESRI (Environmental Systems Research Institute), ArcGIS Desktop, Release 10, ESRI, Redlands, Calif, USA, 2011.

[17] IBM, Statistical Package for Social Science (SPSS), Release 19.0.0, 2010.

[18] Gamma (Gamma Design Software), GS+ User's Guide. 19982008, Version 9, Gamma (Gamma Design Software, Plainwell, Mich, USA, 2008.

[19] ERDAS (Earth Resource Data Analysis System), "ERDAS-ERMapper software," Release 7.2. (free trial) http://erdas-er-mapper .software.informer.com/7.2/.

[20] K. A. Sudduth, N. R. Kitchen, W. J. Wiebold et al., "Apparent electrical conductivity to soil properties across the northcentral USA," Computers and Electronics in Agriculture, vol. 46, no. 1-3, pp. 263-283, 2005. 

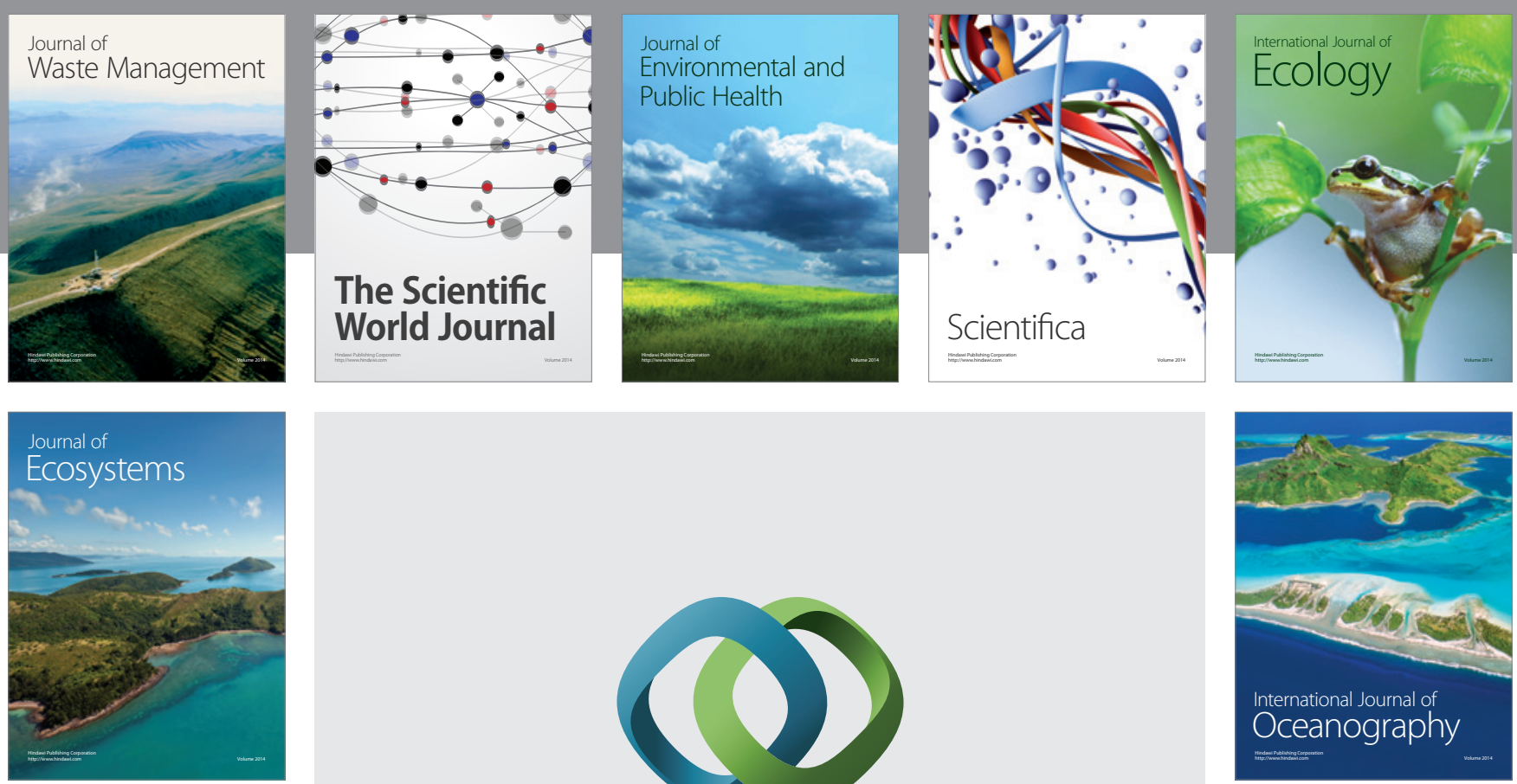

The Scientific World Journal
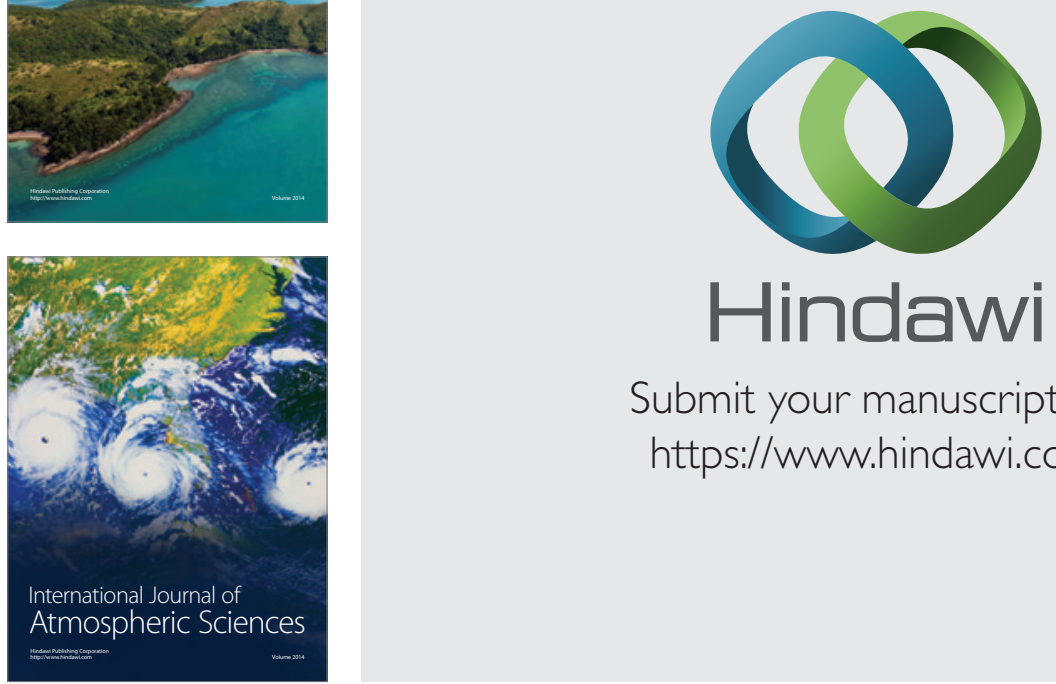

Submit your manuscripts at

https://www.hindawi.com
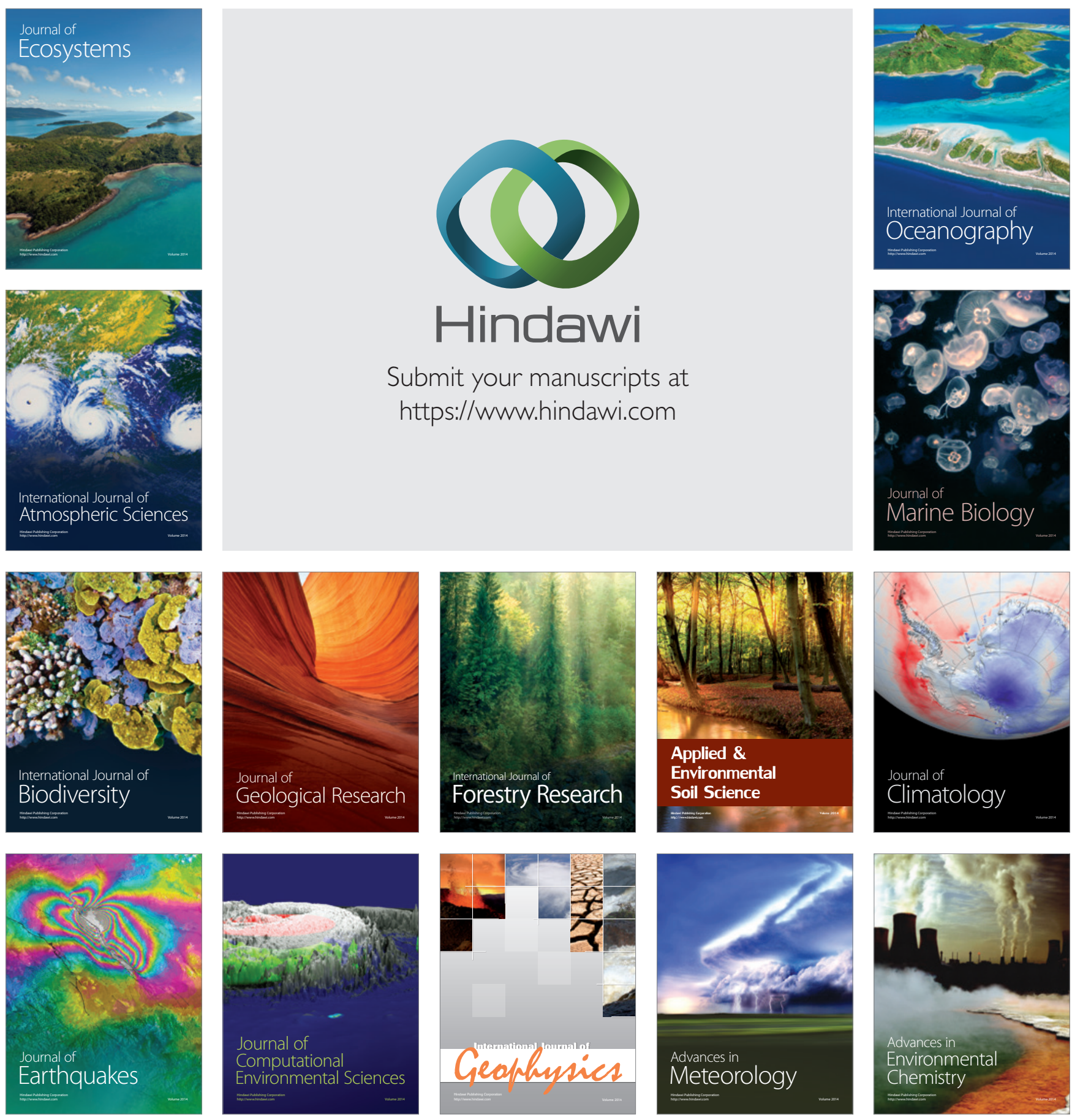